DOI:

УДК 621.79

І.М. Рибалко, к.т.н., irybalko.ua@gmail.com

Харківський національний технічний університет сільського господарства ім. Петра Василенка, м. Харків

\title{
МАТЕМАТИЧНЕ МОДЕЛЮВАННЯ СТРУКТУРОУТВОРЕННЯ ПРИ НАПЛАВЛЕННІ ВІДНОВЛЮВАЛЬНИХ ПОКРИТТІВ 3 ВИКОРИСТАННЯМ МОДИФІКУЮЧӦ̈ ДОМІШКИ БЕНТОНІТОВОЇ ГЛИНИ
}

\begin{abstract}
Використана методика оптико-математичного моделюванням структуроутворення наплавлювальних покриттів з використанням в якості модифікуючої домішки бентонітової глини. Порівняння варіантів наплавлення показало велику однорідність у розподілі фаз при модифікуванні бентонітової глиною. Отримані оброблені зображення на фотографіях в повній мірі відображають структуроутворення при модифікуванні покриттів, де можна простежити не тільки форму і розподіл найбільш твердої фази карбіду, а й оиінити кількість і взаємодію всіх структурних складових.
\end{abstract}

Ключові слова: наплавлення; бентонітова глина; структуроутворення; оптикоматематичний опис.

The technique of optical-mathematical modeling of structure formation of surfacing coatings using bentonite clay as a modifying impurity is used. Comparison of surfacing options showed great homogeneity in the phase distribution when modified with bentonite clay. The obtained processed images in the photographs fully reflect the structure when modifying the coatings, where you can trace not only the shape and distribution of the hardest phase of carbide, but also to estimate the number and interaction of all structural components.

Keywords: surfacing; bentonite clay; structure formation; optical-mathematical description.

\section{Постанова проблеми}

Одним з визнаних способів підвищення терміну служби деталей машин є наплавлення, застосування якого особливо ефективно для збільшення зносостійкості поверхонь, що працюють в умовах контакту з абразивом. Високий опір наплавлених шарів дії зношування, відсутність необхідності в додатковій термічній обробці, можливість отримання необхідних властивостей і хімічного складу, такий процес наплавлення є одним з найпоширеніших методів підвищення довговічності і зносостійкості робочих органів сільськогосподарської техніки.

Відомо, що зносостійкість поверхні в умовах механічного зношування, визначається в першу чергу iї структурно-фазовим складом. Для кожного типу зношення характерно певне поєднання структурно-фазових складових, що забезпечують максимальну зносостійкість поверхні. Процес нанесення покриття має вирішальний вплив на проведення структурно-фазових перетворень в покритті. Широка зміна хімічного складу наплавленого шару залежить від дольової участі основного і присадного матеріалів, високої температури нагріву у діапазоні швидкостей охолодження. Це призводить до формування різних структурно-фазових станів в поверхневому шарі, виконаному одним і тим же наплавлювальним матеріалом.

\section{Аналіз останніх досліджень та публікацій}

У роботах [1-6] представлені математичні моделі, які описують фазові перетворення в зварних з'єднаннях, в тому числі і в сталях. Дані моделі дозволяють спрогнозувати структуру без проведення безліч експериментальних досліджень. Раніше була розроблена і неодноразово описана методика математичного моделювання структуроутворення [7-10]. Дана методика дозволяє досліджувати отриману структуру і виявляти відсоткове співвідношення сформованих фаз, алк в кожному конкретному випадку аналізують додаткові параметри.

\section{Формулювання мети досліджень}

Метою даної роботи стало моделювання структуроутворення з використанням оптикоматематичного опису їі мінливості при введенні модифікуючої домішки глини. 


\section{Виклад основного матеріалу}

Для проведення моделювання структуроутворення використовували оптикоматематичний опис [7-11] ії мінливості при введенні модифікуючої домішки глини в відновлювальне покриття при наплавленні на тонкостінну культиваторну лапу сільськогосподарської техніки. Дослідження базувалися на порівняльному аналізі базового варіанту наплавлення і 3 введенням модифікуючої домішки.

Відомо оптико-математичний опис структуроутворення при зміцнюючому наплавленні при якому використовували модифікування вторинною сировиною з алмазною фракцією від детонації боєприпасів певного набору патронів бойових і освітлювальних та вони детально розглянуті в раніше опублікованих роботах [12-14] і захищені патентами України $[15,16]$, які показали наявність стабільної фази, що формується у вигляді нано- та дисперсних включень алмазів. Перевага використання такого модифікатора полягає в подрібненні структури (особливо включень карбідної фази) за рахунок створення додаткових центрів кристалізації і зниження температури рідкої ванни на $\sim 300^{\circ} \mathrm{C}$ за рахунок того, що такі включення $\epsilon$ мікрохолодильниками, тому що вони розчиняються при $4000^{\circ} \mathrm{C}$, а температура плавлення електрода не перевищує $1600^{\circ} \mathrm{C}$.

В останні $2-3$ роки в ряді країн пройшли конгреси з обговоренням значних матеріальних витрат на виготовлення модифікуючих домішок, і провідні фахівці закликали вчених до пошуку нових джерел використання природних ресурсів. 3 огляду на це, а також ознайомившись $з$ останніми досягненнями науки і техніки в світовій практиці, було виявлено патент США [17], який висвітлював використання бентонітової глини для введення як модифікуючої домішки, що знижує знос, в мастило при експлуатації пар тертя в сполученні.

В ході саміту GMIS 2019 була висловлена думка присутніх про стратегічні можливості розвитку природних технологій в якості нових напрямків розвитку науки і техніки [18]. Одна 3 таких природних технологій може бути використана і в сільськогосподарському машинобудуванні при експлуатації робочих органів машин. Наприклад, в процесі експлуатації культиваторні лапи, працюючи з грунтом, який включає певну кількість піску і глини, взаємодіє з ними i інтенсивно зношує робочий орган. 3 огляду на це, може виявитися ефективним і нанесення відновлюючого покриття на зношені культиваторні лапи, для яких в якості модифікуючої домішки буде використана природна речовина — глина.

Виконане наплавлення двох варіантів - електродом Т-620 і з додатковим модифікуванням бентонітовою глиною $[19,20]$. Вибір цього матеріалу обумовлений тим, що використання в якості модифікатора глини, яка містить оксиди кремнію і алюмінію можуть добре протистояти і чинити опір зносу з аналогічним матеріалам, що входить до складу грунту.

Електрономікроскопічні зображення формуємої структури по перетину покриття металу наплавленим лише електродом і при введенні глини надаються на рис. 1 і 2 . Виявлено відмінність, яка полягає в наступному. При наплавленні тільки електродом формується грубіша структура $з$ протяжними голчастими виділеннями карбідної фази. При модифікуванні глиною такі включення подрібнюються і одночасно з'являються карбідні виділення зернистого типу, рівномірно розподілені по перетину покриття як у вигляді окремих включень, так і зон їх скупчення. Така мінливість гетерогенної структури забезпечує досягнення більшої однорідності в розподілі карбідної складової і меншої схильності іiі до пошкоджуваності при експлуатації. При введенні глини в покриття структура на поверхні і в середній його частині більш однорідна.

За критерієм Колмогорова одержали порівняльні гістограми кольорів фотографій. Аналізували 15 варіантів інтервалів розрахунків. Виявлені несхожі фотографії (наприклад, поверхня і середина, рис. 1 і рис. 2), але $з$ практично близькими гістограмами. Відмінними гістограмами вважали ті, у яких третє число у списку менше 0,5, а за критерієм Колмогорова воно 0,28. Фотографії мікроскопа дозволяють в даному випадку визначити тільки 16 кольорів, хоча їх 256 (розбивали на 15 інтервалів). Розглянемо відміну таблиці по змінам мікроструктури (табл. 1), яка відображає їх на всіх фотографіях. 


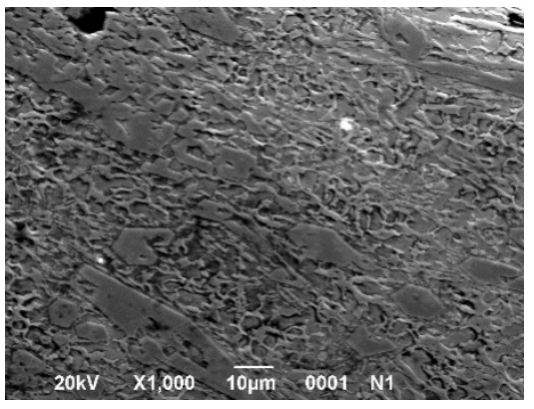

a

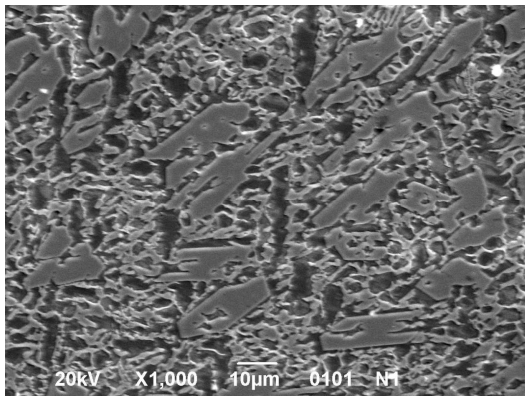

6

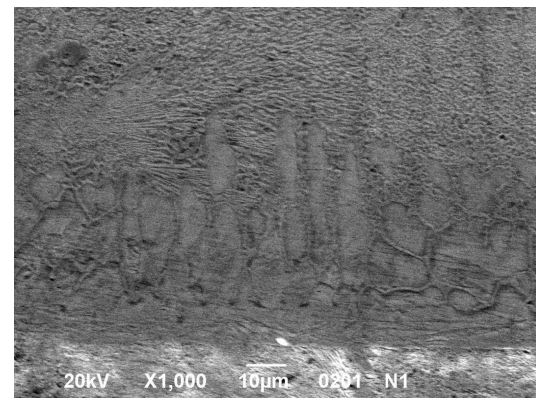

B

Puc. 1. Електронні фотографії структури наплавлених шарів електродом Т-620: a - поверхня наплавлення; 6 - середина; в - зона термічного впливу, $\times 1000$

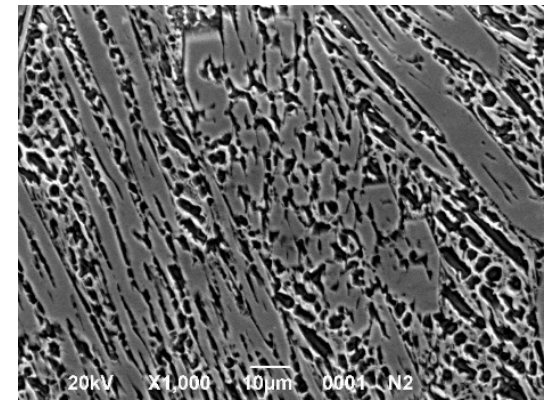

a

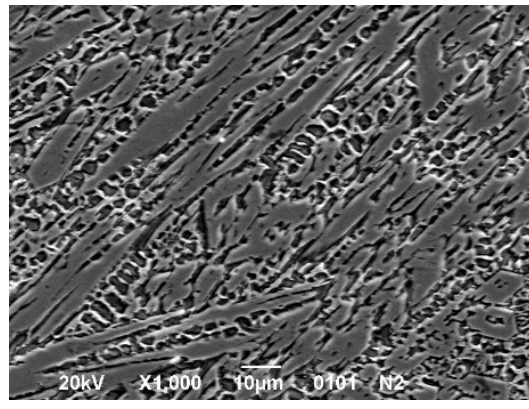

6

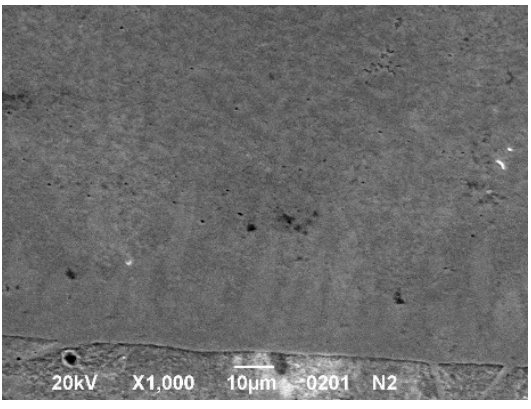

B

Puc. 2. Електрономікроскопічна структура по перерізу покриття наплавленого металу електродом Т-620 при модифікуванні глиною: a - поверхня; $6-$ середина; в - перехідна зона, $\times 1000$

Таблиия 1. Оцифровані фотографії структур з оцінкою зон аналізу (оцінювали як 33 5 балів)

\begin{tabular}{|c|c|c|l|}
\hline $\begin{array}{c}\text { Фотографії структур, які порівнювали } \\
\text { (див. рис. 1 і рис. 2) }\end{array}$ & $\begin{array}{l}\text { Значення за критерієм } \\
\text { Колмогорова }\end{array}$ & \multicolumn{1}{|c|}{ Коментар } \\
\hline 1 & 2 & 0,939 & $\begin{array}{l}\text { Поверхня 1 і середина 1 } \\
\text { схожі }\end{array}$ \\
\hline 1 & 3 & 0,157 & $\begin{array}{l}\text { Поверхня 1 і проміжний шар } \\
\text { не схожі }\end{array}$ \\
\hline 1 & 4 & 0,447 & $\begin{array}{l}\text { Поверхня 1 і поверхня 2 не } \\
\text { схожі }\end{array}$ \\
\hline 1 & 5 & 0,986 & $\begin{array}{l}\text { Поверхня 1 і середина 2 } \\
\text { схожі }\end{array}$ \\
\hline 1 & 3 & 0,011 & $\begin{array}{l}\text { Поверхня 1 і проміжний шар } \\
\text { 2 не схожі }\end{array}$ \\
\hline 2 & 4 & 0,823 & $\begin{array}{l}\text { Середина 1 і проміжний шар } \\
\text { не схожі }\end{array}$ \\
\hline 2 & 5 & 0,923 & $\begin{array}{l}\text { Середина 1 і поверхня 2 } \\
\text { схожі }\end{array}$ \\
\hline 2 & 6 & $\begin{array}{l}\text { Середина 1 і середина 2 } \\
\text { схожі }\end{array}$ \\
\hline 2 & 4 & $\begin{array}{l}\text { Середина 1 і проміжний шар } \\
\text { 2 не схожі }\end{array}$ \\
\hline 3 & 5,0 & $\begin{array}{l}\text { Проміжний шар 1 і поверхня } \\
\text { 2 не схожі }\end{array}$ \\
\hline
\end{tabular}




\begin{tabular}{|c|c|c|l|}
\hline \multicolumn{2}{|c|}{} & \multicolumn{2}{|c|}{ Продовження табл. 1 } \\
\hline 3 & 5 & 0,434 & $\begin{array}{l}\text { Проміжний шар 1 i } \\
\text { середина 2 не схожі }\end{array}$ \\
\hline 4 & 6 & 0,805 & $\begin{array}{l}\text { Проміжний шар 1 i } \\
\text { проміжний шар 2 схожі }\end{array}$ \\
\hline 4 & 5 & 0,984 & $\begin{array}{l}\text { Поверхня 2 і середина 2 } \\
\text { схожі }\end{array}$ \\
\hline 5 & 6 & 0,144 & $\begin{array}{l}\text { Поверхня 2 і проміжний } \\
\text { шар 2 не схожі }\end{array}$ \\
\hline & 6 & 0,052 & $\begin{array}{l}\text { Середина 2 і проміжний } \\
\text { шар 2 не схожі }\end{array}$ \\
\hline
\end{tabular}

Для нанесення покриттів був обраний низьковуглецевий електрод (табл. 2), щоб можна було простежити за впливом легуючих компонентів покриття і дифузію компонентів з підкладки. Виконано розрахунок частки фаз, \%. Розрахунок зроблений для комірок 3 на 3 пікселі.

Таблиия 2. Розподіл фаз в покриттях, що зіставляються, \%

\begin{tabular}{|l|c|c|c|c|c|c|}
\hline \multirow{2}{*}{ Покриття } & \multicolumn{7}{|c|}{ Аналізовані фази і їх сполуки } \\
\cline { 2 - 7 } & $\Phi$ & Б & К & $\Phi+$ Б & Б + К & $\Phi+$ Б + К \\
\hline $\begin{array}{l}\text { Без модифікато- } \\
\text { ра }\end{array}$ & $\begin{array}{c}61,5 *)- \\
92,2\end{array}$ & $2,8-9,4$ & $0,7-6,9$ & $2,6-18,0$ & $1,2-4,05$ & $2,7-17,7$ \\
\hline Середні значення & 83,0 & 5,1 & 2,5 & 6,3 & 2,2 & 8,2 \\
\hline $\begin{array}{l}\text { 3 додаванням } \\
\begin{array}{l}\text { бентонітової } \\
\text { глини }\end{array}\end{array}$ & $69,1-92,2$ & $6,4-2,8$ & $6,9-0,9$ & $8,6-4,4$ & $4,2-2,6$ & $11,2-2,0$ \\
\hline Середні значення & 85,0 & 4,8 & 3,3 & 6,7 & 3,1 & 6,6 \\
\hline
\end{tabular}

Примітка: *) перші цифри в межах значень відображають верх покриття, а другі перехідну зону.

Як встановлено аналізом таблиць, в різних зонах покриттів частка феритної складової без модифікатора змінюється від 61,5 до 92,2 \% (середнє 83\%), бейниту $2,8-9,4 \%$ (середнє $5,1 \%$ ), карбіду $0,7-6,9 \%$ (середнє 2,5 \%). Кількість поєднання фаз характерно як для парних, так і потрійних взаємодій. При поєднанні ферит-бейниту воно змінюється від 2,6 до 18,0% (середнє 6,3\%), бейнит-карбіду $1,2-4,05 \%$ (середнє 2,2 \%), ферит-бейнит-карбіду 2,7-17,7 \% (середне 8,2 \%). Отримані дані свідчать про те, що якість металу покриття без додаткового модифікування відрізняється істотною неоднорідністю.

При модифікуванні покриття бентонітовою глиною картина співвідношення і частка фаз відрізняється.

Кількість фериту збільшується до перехідного шару, і його частка змінюється від 69,1 до 92,2 \% (середнє $85 \%$ ), бейніту 6,4-2,8\% (середнє 4,8\%), карбідів 6,9-0, 9 \%(середнє $3,3 \%)$.

Взаємодія фаз при введенні бентонітової глини відповідає: ферит-бейніт 8,6-4,4 \% (середнє 6,7\%), бейніт-карбіди 4,2-2,6 \% (середнє 3,1 \%), ферит-бейніт-карбіди (середнє 6,6 \%).

Виходячи 3 порівняльного аналізу (табл. 2), середні показники нанесення покриття без модифікуючої домішки і з ії введенням (бентонітової глини) характеризуються тим, що розглянутий новий технологічний процес не змінює частки і розподілу феритної складової, проте на 5,9 \% знижується - бейнітна, а з'єднання ферит-бейніт-карбіди, в середньому, вище на 20 \%. Одночасно підвищується середня частка карбідної складової в модифікованому покритті на $32 \%$, а ферито-бейнітної на $\sim 20 \%$. Крім того, виявлена цікава залежність, що характеризує взаємодію фаз ферит-бейніт-карбіди в перехідній зоні, і підвищена кількість групи фаз, яка досягає $17,7 \%$ у вихідному металі з покриттям, що в 8,8 разів більше, ніж при модифікуванні. 
У цій зоні без модифікування істотно збільшується і частка чистої фази карбіду — до 11 разів, що сприяє утворенню тріщин в тонкостінному виробі при наплавленні культиваторною лапи товщиною 5-6 мм. Спостережувана зміна структурного стану може бути також пов'язана і 3 збільшеними локальними напруженнями в покритті без введення модифікуючої домішки i більш високою температурою рідкої ванни, а також інтенсифікацією дифузії з підкладки, що і підтверджують дослідження [18].

На підставі розрахунків отримані рисунки, які описують поєднання кольорів (для випадків більше $1 \%$ ). Таких поєднань отримано 32 для кожної зони покриття. Аналогічне поєднання кольорів виконано для кожного варіанта описуфотографії мікроструктур покриття (верх, середина, перехідна зона).

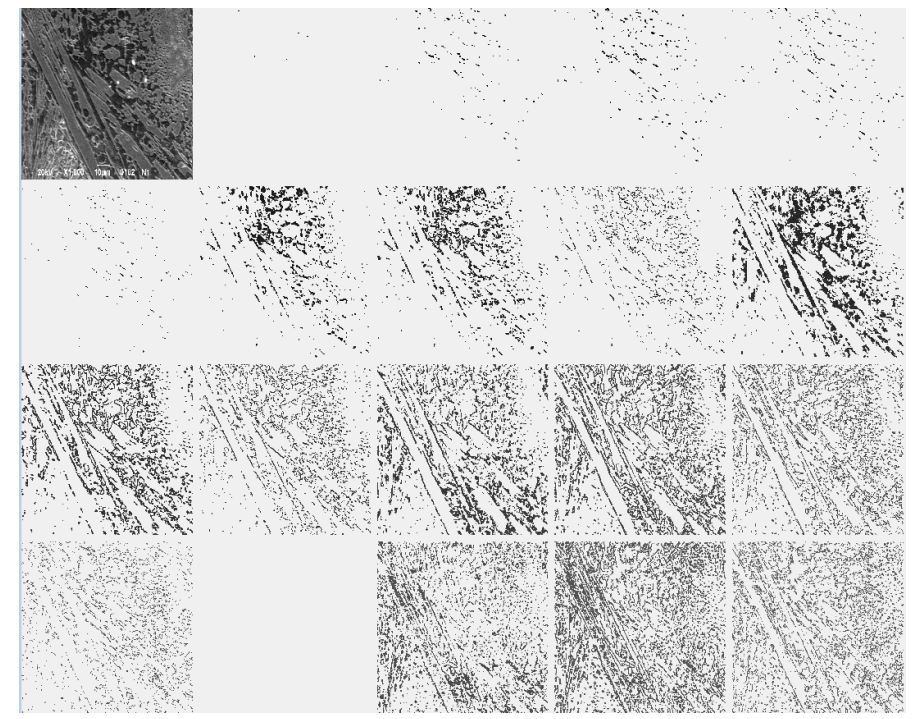

a

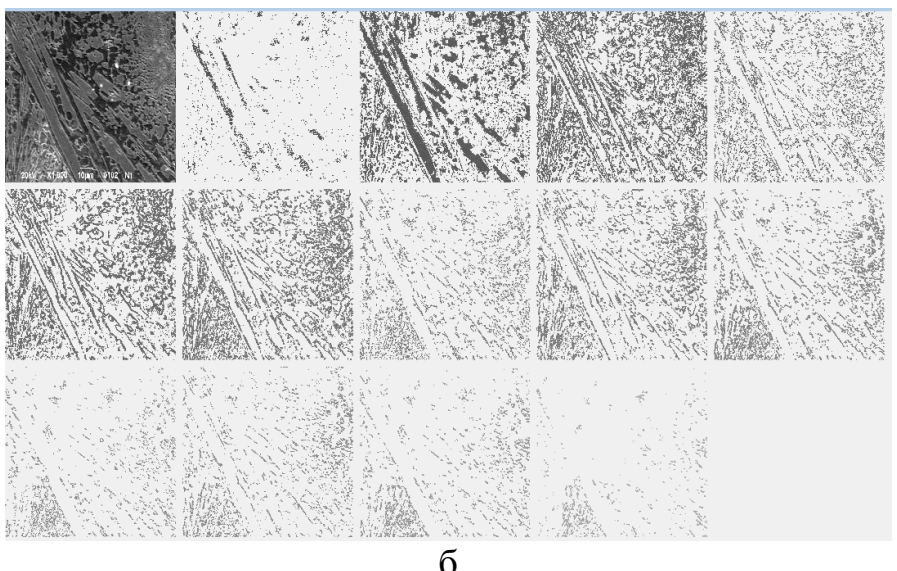

6

Рис. 3. Характерні зображення електронних мікрофотографій структури при взаємодії фаз в середині покриття без модифікування

На рис. 3, а та 4, а наведені структури поєднань (взаємодії) з 1 по 19. Решта на рис. 3, б та 4, б:головним чином це феритні поєднання (01-09) і тільки п'ять включають: одна бейніту (10), три карбідні $\mathrm{FeC}(11)$ і інші теж не стехіометричного складу $\mathrm{Fe}_{\mathrm{x}} \mathrm{C}_{\mathrm{y}}(12,13)$. Нумерація зображень зліва направо, зверху вниз. У самому верхньому лівому кутку приведена вихідна фотографія оцифрованої структури, яку піддавали обробці оптико-математичним методом.

Представлені фотографії в повній мірі відображають металографічну картину розподілу теоретично оцінених фаз і їх поєднань, які підтверджують мінливість структуроутворення. 

риттів.

На рис. 3 і 4 наведені вибірково лише порівняльні дані середньої зони нанесених пок-

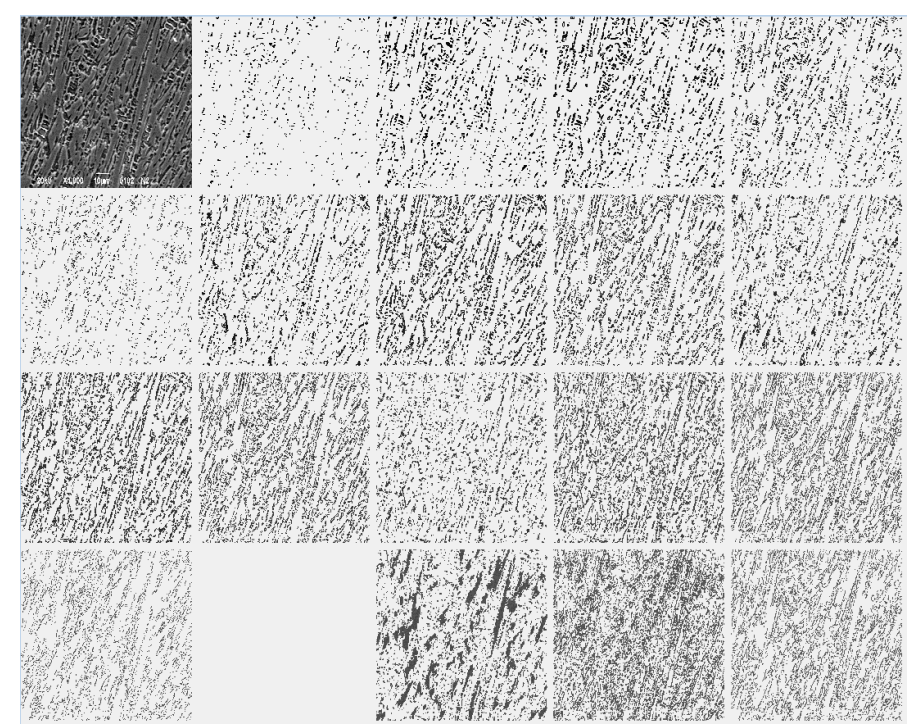

$\mathrm{a}$

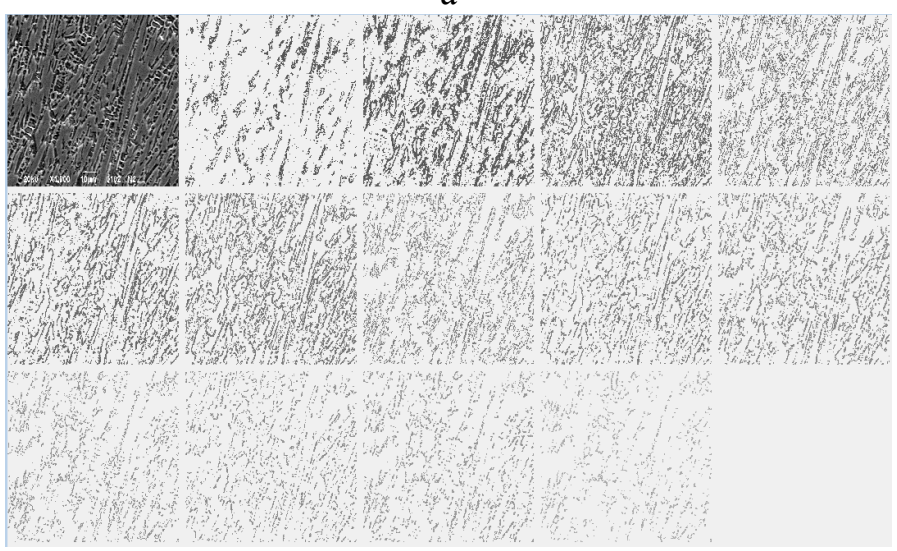

б

Рис. 4. Характерні зображення електронних мікрофотографій структури при взаємодії фаз в середині покриття з введенням модифікатора бентонітової глини

Аналізом мікроструктури показано, що існують помітні відмінності не тільки в частці фаз, але і між розподілом варіантів нанесення покритті, що зіставляються. Це характерно для всіх зон покриттів без модифікуючої домішки. У цьому варіанті межа сплаву грубіша, потовщена 3 карбідами витягнутими пластинчастими включеннями уздовж відведення тепла в основний метал відновлюваної деталі.

При модифікуванні структура покриття більш однорідна і вона характеризується великою кількістю точкових включень карбідів, виділених як по межах окремих роздроблених пластинчастих виділень, так і між ними.

Виходячи з отриманих результатів, слід оцінити вплив і інших типів глини різних родовищ, які можуть відрізнятися хімічним складом, зернистістю, ступенем вологості, наявністю шкідливих домішок і мікродомішками. Такі дослідження будуть достатніми при аналізі складу глини, мінливості структури, можливості використання для тонкостінних виробів при зміцненні культиваторних лап при виробництві та їх відновлення при експлуатації. 


\section{Висновки}

Вперше для модифікування рідкої ванни зміцнюючого покриття використовували природну модифікуючу домішку — глину та виконали аналіз структурних змін в покритті оптикоматематичним описом фаз і їх частки відносно вихідного стану.

Для цього за критерієм Колмогорова порівнювали гістограми кольорів фотографій. Аналізували статистичні результати по 15 інтервалах фаз, що формуються. В даному варіанті досліджень використовували для наплавлення покриття вуглецевий електрод, щоб чітко виявити вплив модифікуючої домішки.

Порівняння показало велику однорідність у розподілі фаз при модифікуванні бентонітової глиною.

Отримані зображення на фотографіях в повній мірі відображають структуроутворення при модифікуванні покриттів, де можна простежити не тільки форму і розподіл найбільш твердої фази карбіду, а й оцінити кількість і взаємодію всіх структурних складових.

Дослідженнями показали, що додаткове модифікування бентонітовою глиною 3 часткою 5-7 \% від долі електроду забезпечує підвищення феритної складової на 2,4 \%, карбідів на $32 \%$, зниження бейнітної на $5,4 \%$, а також змінює взаємодію фаз, яка забезпечує зменшення розміру зерен, напружень у перехідній зоні.

\section{Список використаних джерел}

1. Radaj D. Heateffectsofwelding: Temperaturefield, residualstress, distortion. Berlin: Springer, 1992. $322 \mathrm{p}$.

2. Костин В.А., Григоренко Г.М., Жуков В.В., Крупеник А.М. Особенности моделирования структурных превращений в сварных швах высокопрочных сталей. Сборник трудов 6-й конференции «Математические модели и информационные технологии в сварке и родственных проиессах». 2012. С. 233-235.

3. Костин В.А. Моделирование структурных превращений и механических свойств в сварных швах высокопрочных низколегированных сталей.Сборник трудов 7-й конференции «Математические модели и информачионные технологии в сварке и родственных проиессах». 2014. C. 146-147.

4. Троцан А.И., Каверинский В.В., Бродецкий И.Л., Сухенко З.П. Компьютерное моделирование фазовых превращений в комплексно легированной стали. Строительство, материаловедение, машиностроение: Стародубовские чтения 2016. 2016. Вып. 89. С. 177-181.

5. Каверинский В.В., Троцан А.И., Баглюк Г.А., Сухенко З.П. Математическое моделирование структурообразования в зоне термического влияния сварного шва низкоуглеродистой среднелегированной стали.Металлургическая и горнорудная промышленность. 2017. №5. С. 51-56.

6. Васильев А.А, Колбасников Н.Г., Соколов Д.Ф., Соколов С.Ф. Моделирование микроструктуры и механических свойств стального листа после прокатки на стане 2000 ОАО «Северсталь». Вопросы материаловедения. 2010. № 3 (63). С. 16-27.

7. Skoblo T. $\square$ S., Klochko O. $\square$ Yu., Belkin E. $\square$ L., Sidashenko A. $\square$ I., New Approaches in Study of Inhomogeneity of Heterogeneous Structures. Metallofiz. Noveishie Tekhnol.2018. 40, No. 2. pp. 255-280. https://doi.org/10.15407/mfint.40.02.0255

8. Skoblo T.S., Klochk oO.Y., Belkin E.L.,Sidashenko A.I., Avetisyan V.K. Structure formation of high-chromium cast irons in the temperature range of the magnetic transformation of carbide phases. Lett. Mater. 2020. 10(2).pp. 129-134. https://doi.org/10.22226/2410-3535-2020-2-129-134

9. Скобло Т.С., Клочко О.Ю., Сідашенко О.І., Белкін Й.Л., Автухов А.К., Мальцев Т.В., Дерябкіна Є.С., Колпаченко Н.М. Оцінка деградації карбідних фаз у хромонікелевому чавуні за температур експлуатації прокатних валків. Фізико-хімічна механіка матеріалів. 2020. ТОМ 56, № 6. C. 45-51.

10. Skoblo T.S., Belkin E.L., Klochko O.Yu. Application justification of the concepts of fluid dynamics Navier-Stokes equations for the analysis of metallographic images. Materiaty VII Mięzdynarodowej naukowi-praktycznej konferencji.2011. Vol. 21. pp. 94-96. 
11. Скобло Т.С., Клочко О.Ю., Белкин Е.Л. Применение компьютерног оанализа металлографических изображений при исследовании структурывы сокохромистого чугуна. Заводская лаборатория. Диагностика материалов. 2012. Т. 78. № 6. С. 35-42.

12. Скобло Т.С., Сідашенко А.І., Сайчук О.В. Корпусні деталі з чавунів та їх якісні показники. Х.: Діса плюс, 2019. 282 с.

13. Марков А.В. Повышение эксплуатационной стойкости деталей сельскохозяйственного машиностроения с применением вторичного сырья. Научно-практический журнал «Агротехника и энергообеспечение».2015. № 5 (9). С. 12-25.

14. Нанка О.В., Рибалко І.М., Марков О.В. Модифікування відновлюваних шарів вуглецьвмісними домішками.Информационно-аналитический международный технический журнал «Промышленность в фокусе». 2018. № 1 (62). С. 53-58.

15. Спосіб одержання детонаційної шихти 3 алмазною фракцією:пат. 138685 Україна, МПК (2006)B22D 19/00, B22D 19/08 (2006.01). № u201904939; заявл. 10.05.2019; опубл. 10.12.2019, Бюл. № 23.

16. Спосіб використання детонаційної шихти для зміцнення відновлювального шару деталей:пат. 98213 Україна,МПК (2006) В32В 5/14 (2006.01). № u201410552; заявл. 26.09.2014; опубл. 27.04.2015, Бюл. № 8.

17. Nano-particle metal treatment composition for creating a ceramic-metal layer: Patent 7,304,020B1USA, Int. Cl. B22C 23/02 (2006.01).Appl. No.: 11/465,852; Filed: Aug. 21, 2006; Date of Patent: Dec. 4, 2007.

18. Курчатовский институт: Проблему ресурсосбережения решат природоподобные технологии: веб-сайт.

URL:https://news.sputnik.ru/ekonomika/8f51 fa430f49a1b8ee5397de64261bb486743091

(дата звернення: 20.04.2021).

19. Скобло Т.С., Рыбалко И.Н., Сидашенко А.И., Тихонов А.В. Применение модифицирующей присадки - глины при восстановительной наплавке деталей.Сварочное производство. 2020. № 7. С. 41-49.

20. Спосіб підвищення зносостійкості стрілчастої лапи культиватора:пат. 130824Україна,МПК (2006)A01B 23/00, А01В 35/00. № u201806896; заявл. 19.06.2018; опубл. 26.12.2018, Бюл. № 24 .

\section{MATHEMATICAL MODELING OF THE STRUCTURE FORMATION IN THE SURFACE OF REPAIR COATINGS USING A MODIFYING ADDITIVE OF BENTONITE CLAY Rybalko I.}

\section{Abstract}

The coating process has a decisive influence on the structural and phase transformations in the coating. A wide change in the chemical composition of the deposited layer depends on the share of the main and filler materials, high heating temperature in the range of cooling rates. This leads to the formation of different structural-phase states in the surface layer made of the same surfacing material.

The aim of this work was to model the structure using an optical-mathematical description of its variability with the introduction of a modifying clay impurity.

An optical-mathematical description of its variability during the introduction of a modifying clay impurity into the restorative coating during surfacing on a thin-walled cultivator paw of agricultural machinery was used to model the formation. The studies were based on a comparative analysis of the basic variant of surfacing and with the introduction of a modifying impurity. For the first time, a natural modifying impurity, clay, was used to modify the liquid bath of the reinforcing coating and the analysis of structural changes in the coating was performed by optical-mathematical description of the phases and their fraction relative to the initial state. 
To do this, the color histograms of the photographs were compared according to Kolmogorov's criterion. Analyzed statistical results on 15 intervals of the formed phases. In this embodiment, the carbon electrode was used to weld the coating to clearly detect the effect of the modifying impurity. The comparison showed great homogeneity in the phase distribution when modified with bentonite clay.

The obtained images in the photographs fully reflect the structure formation when modifying the coatings, where it is possible to trace not only the shape and distribution of the hardest carbide phase, but also to estimate the number and interaction of all structural components. Studies have shown that additional modification with bentonite clay with a share of $5-7 \%$ of the electrode fraction increases the ferrite component by $2.4 \%$, carbides by $32 \%$, reduces bainite by $5.4 \%$, and changes the phase interaction, which reduces the size grains, stresses in the transition zone.

\section{References}

[1] Radaj D. (1992). Heat effects of welding: Temperature field, residual stress, distortion. Berlin: Springer.

[2] Kostin V.A., Grigorenko G.M., Zhukov V.V., Krupenik A.M. (2012) Osobennosti modelirovanija strukturnyh prevrashhenij $\mathrm{v}$ svarnyh shvah vysokoprochnyh stalej[Features of modeling of structural transformations in welded joints of high-strength steels].Sbornik trudov 6-j konferencii "Matematicheskie modeli i informacionnye tehnologii $v$ svarke $i$ rodstvennyh processah" Proceedings of the 6th conference "Mathematical models and information technologies in welding and related processes", Kaceveli [in Russian].

[3] Kostin V.A. (2014) Modelirovanie strukturnyh prevrashhenij i mehanicheskih svojstv v svarnyh shvah vysokoprochnyh nizkolegirovannyh stalej [Modeling of structural transformations and mechanical properties in welds of high-strength low-alloy steels].Sbornik trudov 7-j konferencii «Matematicheskie modeli i informacionnye tehnologii v svarke $i$ rodstvennyh processah» Proceedings of the 7th conference "Mathematical models and information technologies in welding and related processes", Odessa [in Russian].

[4] Trocan A.I., Kaverinskij V.V., Brodeckij I.L., Suhenko Z.P. (2016) Komp'juternoe modelirovanie fazovyh prevrashhenij $\mathrm{v}$ kompleksno legirovannoj stali[Computer simulation of phase transformations in complex alloyed steel].Stroitel'stvo, materialovedenie, mashinostroenie: Starodubovskie chtenija 2016 - Construction, materials science, mechanical engineering: Starodubov readings 2016, Vyp. 89, 177-181 [in Russian].

[5] Kaverinskij V.V., Trocan A.I., Bagljuk G.A., Suhenko Z.P. (2017) Matematicheskoe modelirovanie strukturoobrazovanija $\mathrm{V}$ zone termicheskogo vlijanija svarnogo shva nizkouglerodistoj srednelegirovannoj stali [Mathematical modeling of structure formation in the heat-affected zone of the welded seam of low-carbon medium-alloyed steel]. Metallurgicheskaja $i$ gornorudnaja promyshlennost' -Metallurgicalandminingindustry, № 5, 51-56 [in Russian].

[6] Vasil'ev A.A, Kolbasnikov N.G., Sokolov D.F., Sokolov S.F. (2010) Modelirovanie mikrostruktury i mehanicheskih svojstv stal'nogo lista posle prokatki na stane 2000 OAO «Severstal'»[Modeling the microstructure and mechanical properties of a steel sheet after rolling in a 2000 mill at Severstal].Voprosy materialovedenija - Materials science issues, № 3(63), 1627 [in Russian].

[7] Skoblo T. $\square$ S., KlochkoO. $\square$ Yu., Belkin E. $\square$ L., Sidashenko A. $\square$ I. (2018) New Approaches in Study of Inhomogeneity of Heterogeneous Structures.Metallofiz. Noveishie Tekhnol.,40, No. 2, 255-280. https://doi.org/10.15407/mfint.40.02.0255 [in Russian].

[8] Skoblo T.S., Klochko O.Y., Belkin E.L.,Sidashenko A.I., Avetisyan V.K. (2020)Structure formation of high-chromium cast irons in the temperature range of the magnetic transformation of carbide phases. Lett. Mater., 10(2), 129-134. https://doi.org/10.22226/2410-3535-2020-2-129134 [in Russian].

[9] Skoblo T.S., Klochko O.Iu., Sidashenko O.I., Belkin Y.L., Avtukhov A.K., Maltsev T.V., Deriabkina Ye.S., Kolpachenko N.M. (2020) Otsinka dehradatsii karbidnykh faz u khromonikelevomu chavuni za temperatur ekspluatatsii prokatnykh valkiv [Estimation of degradation of carbide phases in chromium-nickel cast iron at operating temperatures of rolling 
rolls]. Fizyko-khimichna mekhanika materialiv - Physico-chemical mechanics of materials, T. 56, № 6, 45-51 [in Ukrainian].

[10] Skoblo T.S., Belkin E.L., Klochko O.Yu. (2011) Application justification of the concepts of fluid dynamics Navier-Stokes equations for the analysis of metallographic images. Materiaty VII Mięzdynarodowej naukowi-praktycznej konferencji. Przemyśl, Vol. 21, 94-96 [in Russian].

[11] Skoblo T.S., Klochko O.Yu., Belkin E.L. (2012) Implementation of computer analysis for metallographic images in the study of structure of high-chromium cast iron. Industrial laboratory. Diagnostics of materials, 78(6), 35-42 [in Russian].

[12] Skoblo T.S., Sidashenko A.I., Saichuk O.V. (2019) Korpusni detali z chavuniv ta yikh yakisni pokaznyky [Cast iron body parts and their quality indicators]. Kharkiv: Disa plius. [inUkrainian].

[13] Markov A.V. (2015) Povyshenie jekspluatacionnoj stojkosti detalej sel'skohozjajstvennogo mashinostroenija s primeneniem vtorichnogo syr'ja[Increasing the operational durability of agricultural engineering parts using secondary raw materials]. Nauchno-prakticheskij zhurnal «Agrotehnika i jenergoobespechenie» - Scientific and practical journal "Agrotechnics and energy supply", № 5 (9), 12-25 [in Russian].

[14] Nanka O.V., Rybalko I.M., Markov O.V. (2018) Modyfikuvannia vidnovliuvanykh shariv vuhletsvmisnymy domishkamy[Modification of renewable layers with carbon-containing impurities].Informacionno-analiticheskij mezhdunarodnyj tehnicheskij zhurnal "Promyshlennost" $v$ fokuse» - Information and analytical international technical journal "Industry in focus", № 1(62), 53-58 [in Ukrainian].

[15] Skoblo T.S., Nanka O.V., Sidashenko O.I., Kuskov Y.M., Saychuk O.V., Romanyuk S.P., Markov O.V., Samsonov Yu.V. (2019) Patent of Ukraine 138685. Kyiv: State Patent Office of Ukraine [in Ukrainian].

[16] Skoblo T.S., Sidashenko O.I., Goncharenko O.O., Markov O.V., Afanasyev V.V.(2015) Patent of Ukraine 98213. Kyiv: State Patent Office of Ukraine [in Ukrainian]

[17] Dmitry Tananko, Olena Lyubchenko, Oleksandr Oliinik, Oleksandr Umanskiy, Svitlana Aksyonova (2007) Patent USA No 7,304,020B1. Washington, DC: U.S. Patent and Trademark Office.

[18] Kurchatov Institute: The problem of resource conservation will be solved by natural technologies. Retrieved

from:https://news.sputnik.ru/ekonomika/8f51fa430f49a1b8ee5397de64261bb486743091 [in Russian].

[19] Skoblo T.S., Rybalko I.N., Sidashenko A.I., Tihonov A.V. (2020) Primenenie modificirujushhej prisadki - gliny pri vosstanovitel'noj naplavke detalej [The use of a modifying additive - clay in the restoration surfacing of parts]. Svarochnoe proizvodstvo - Welding production, № 7, 41-49 [in Russian].

[20] Skoblo T.S., Sidashenko O.I., Rybalko I.M., Tikhonov O.V., Oleynik O.K. (2018) Patent of Ukraine 130824. Kyiv: State Patent Office of Ukraine [in Ukrainian]. 